\title{
Original Research \\ Hyperlipidemia medication management in patients admitted for a myocardial infarction
}

\author{
Jerrica E. SHUSTER, Meghan N. JEFFRES, Sean M. BARCLAY, Ragini BHAKTA. \\ Received (first version): 1-Oct-2010 \\ Accepted: 11-Jan-2011
}

\begin{abstract}
$^{*}$
Objectives: The purpose of this study is to determine the percentage of patients admitted for acute myocardial infarction currently prescribed a statin, with low-density lipoprotein (LDL) $<100$ $\mathrm{mg} / \mathrm{dL}$, and high-density lipoprotein (HDL) $<50$ $\mathrm{mg} / \mathrm{dL}$ for men and $<55 \mathrm{mg} / \mathrm{dL}$ for women and evaluate their medication management with a focus on niacin initiation.

Methods: This was a retrospective study from 12/07 to $12 / 09$, conducted at a private, community hospital. Inclusion criteria required patients to have an acute myocaridal infarction (AMI) ICD-9 code, troponin $\geq 0.2 \mathrm{ng} / \mathrm{dL}$ and lipid panel performed within 96 hours of troponin. Patients with a triglyceride level $>400 \mathrm{mg} / \mathrm{dL}$ were excluded. The residual risk population consisted of patients currently taking a statin with LDL $<100 \mathrm{mg} / \mathrm{dL}$ and $\mathrm{HDL}<50 / 55 \mathrm{mg} / \mathrm{dL}$. Patients were excluded from the residual risk population if they were on niacin, had an allergy to or previously failed niacin therapy, or expired within 72 hours.

Results: A total of 553 patients experiencing an AMI had lipid panels available for evaluation. The mean LDL was $97.3 \pm 36.0 \mathrm{mg} / \mathrm{dL}$, mean HDL was $33.5 \pm$ $11.1 \mathrm{mg} / \mathrm{dL}$, and mean triglycerides were $133.1 \pm$ $71.3 \mathrm{mg} / \mathrm{dL}$. The majority of patients ( $\mathrm{n}=521,94.2 \%$ ) had an $\mathrm{HDL}<50$ or $55 \mathrm{mg} / \mathrm{dL}$ respective of gender. Ninety-two $(80.0 \%)$ residual risk patients had no change in their home lipid medications post AMI. Fifteen $(13.0 \%)$ residual risk patients had their dose of statin medication increased. Seven (6.1\%) residual risk patients were initiated on niacin. Conclusions: The study results confirm an existence of a residual risk population with nearly $25 \%$ of AMI patients meeting the criteria. The results also confirm a low incidence of medication intervention in the residual risk population post AMI (20.0\%) regarding lipid therapy, including the initiation of niacin in only $6.1 \%$ of patients.
\end{abstract}

\footnotetext{
*Jerrica E. SHUSTER. Pharm.D. University of Southern Nevada College of Pharmacy. Henderson, NV (United States).

Meghan N. JEFFRES. Pharm.D., BCPS. University of Southern Nevada College of Pharmacy; University Medical Center of Southern Nevada Department of Pharmacy; and University of Nevada School of Medicine Department of Internal Medicine. Henderson, NV (United States). Sean M. BARCLAY. Pharm.D., BCPS. University of Southern Nevada College of Pharmacy; University Medical Center of Southern Nevada Department of Pharmacy; and University of Nevada School of Medicine Department of Internal Medicine. Henderson, NV (United States). Ragini BHAKTA. Pharm.D., BCPS.University of Southern Nevada College of Pharmacy, and St. Rose Dominican Hospital Department of Pharmacy. Henderson, NV (United States).
}

Keywords: Myocardial Infarction. Niacin. Cholesterol, HDL. United States.

\section{MANEJO DE LA MEDICACIÓN PARA HIPERLIPEMIA EN PACIENTES INGRESADOS POR INFARTO DE MIOCARDIO}

\section{RESUMEN}

Objetivos: El propósito de este estudio es determinar el porcentaje de pacientes ingresados por un infarto agudo de miocardio que tienen actualmente prescrita una estatina, con lipoproteínas de baja densidad (LDL) $<100 \mathrm{mg} / \mathrm{dL}$, y lipoproteínas de alta densidad (HDL) $<50 \mathrm{mg} / \mathrm{dL}$ para hombres y $<55 \mathrm{mg} / \mathrm{dL}$ para mujeres, y evaluar el manejo de su medicación centrándose en la iniciación a niacina.

Métodos: Este fue un estudio retrospectivo de $12 / 07$ a $12 / 09$, realizado en un hospital comunitario privado. Los criterios de inclusión requerían que los pacientes tuviesen un código CIE-9 de infarto agudo de miocardio (IAM), troponina $\geq 0.2 \mathrm{ng} / \mathrm{dL}$ y un panel lipídico realizado en las 96 horas de la troponina. Los pacientes con nivel de triglicéridos $>400 \mathrm{mg} / \mathrm{dL}$ fueron excluidos. La población de riesgo residual consistió en pacientes que tomaban actualmente estatinas con $\mathrm{LDL}<100 \mathrm{mg} / \mathrm{dL}$ y $\mathrm{HDL}<50 / 55 \mathrm{mg} / \mathrm{dL}$. Se excluía a los pacientes de la población de riesgo residual si estaban con niacina, tenían alergia o fallo previo a la niacina, o fallecieron en las 72 horas.

Resultados: Un total de 553 pacientes que sufrieron un IAM tenían un perfil lipídico disponible para evaluación. La media de LDL fue de 97,3 $(\mathrm{DE}=36,0) \mathrm{mg} / \mathrm{dL}$, la media de HDL fue de 33,5 $(\mathrm{DE}=11,1) \mathrm{mg} / \mathrm{dL}$, y la media de triglicéridos fue de $133,1(\mathrm{DE}=71,3) \mathrm{mg} / \mathrm{dL}$. La mayoría de los pacientes $(n=521,94.2 \%)$ tenían HDL $<50$ o 55 $\mathrm{mg} / \mathrm{dL}$, respectivamente del su género. $92(80,0 \%)$ pacientes de riesgo residual no tuvo cambios en su medicación domiciliaria de lípidos después del IAM. A $15(13,0 \%)$ pacientes de riesgo residual se le aumentó la dosis de estatinas. En $7(6,1)$ pacientes de riesgo residual se inició la niacina. Conclusiones: Los resultados del estudio confirman la existencia de una población de riesgo residual de cerca del $25 \%$ de pacientes con IAM que satisface los criterios. Los resultados también confirman la baja incidencia de intervención en la población de riesgo residual post-IAM $(20,0 \%)$ en relación al tratamiento para los lípidos, incluyendo la iniciación de niacina en sólo el 6,1\% de los pacientes. 
Palabras clave: Infarto de miocardio. Niacina. Colesterol HDL. Estados Unidos.

\section{INTRODUCTION}

Despite significant progress in cardiovascular disease (CVD) management with stains and aggressive lowering of low-density lipoprotein (LDL), CVD continues to be the leading cause of death worldwide. ${ }^{1}$ This prompts the pursuit for novel strategies to decrease cardiovascular risk and has increased the interest in low high-density lipoprotein (HDL) as a therapeutic target. ${ }^{2}$ HDL has been shown to have an independent inverse relationship with coronary heart disease (CHD) event rates, in which CHD risk declines by $2-3 \%$ for a $1 \mathrm{mg} / \mathrm{dL}$ increase in HDL levels. ${ }^{3}$ This relationship becomes more notable when the prevalence of low HDL $(<40$ $\mathrm{mg} / \mathrm{dL}$ ) among Americans age 20 and older is considered; with an overall incidence estimated at nearly $50 \%$ of Americans. ${ }^{4}$ Currently, the most effective drug therapy available for raising HDL is niacin, showing increases of 15 to 35 percent. $^{5-9}$

Due to the relative potency of niacin in increasing HDL compared to other medications, supplemental treatment with niacin is gaining attention as pharmacotherapy extends beyond statin monotherapy. Even after patients are treated with high-dose statins and have met the aggressive optional low-density lipoprotein cholesterol (LDL) goal of less than $70 \mathrm{mg} / \mathrm{dL}$, a risk for cardiovascular events (CVE) still exists, often referred to as residual risk. ${ }^{10}$ The investigators of the Treating to New Targets (TNT) trial reported in a post hoc analysis that HDL level was predictive of CVE in patients being treated with statins, including patients with LDL of less than $70 \mathrm{mg} / \mathrm{dL}$ and increasing HDL could decrease this residual risk. ${ }^{11}$

Studies have shown a relationship between increasing HDL concentrations with niacin and a decrease in occurrence of CVE and possibly mortality. ${ }^{12-16}$ It is important to note that the improvement in outcomes in these trials is attributed to the increase in $\mathrm{HDL}$, not the decrease in LDL or triglycerides (TG). The present study investigates the lipid panels of patients with an acute myocardial infarction (AMI) to determine the occurrence of residual risk patients experiencing an $\mathrm{AMI}$, and evaluate their medication management with a specific focus on niacin initiation.

\section{METHODS}

\section{Study location and patients}

This study was conducted at a private, community hospital, Saint Rose Dominican Hospital- Siena Campus (219 beds). During a 2-year period (December 2007 to December 2009), all patients with an ICD-9 code of acute myocardial infarction (410.00-410.92), with a serum troponin concentration greater than or equal to $0.2 \mathrm{ng} / \mathrm{mL}$, and a lipid panel performed within 96 hours of the serum troponin concentration were eligible for this study. ${ }^{17}$ Lipid panels containing a triglyceride value of greater than $400 \mathrm{mg} / \mathrm{dL}$ were excluded due to decreased accuracy of the calculated LDL. A subset of patients, defined as the residual risk patient group, was analyzed and included those on a statin prior to hospitalization and at LDL goal, but not at HDL goal. Patients were excluded from this subset if their home medications included niacin, had a documented allergy to niacin or previously failed niacin therapy, or expired less than 72 hours after hospital admission. This study was approved by the Western Institutional Review Board and informed consent was waived.

\section{Study design and data collection}

A retrospective, descriptive study design was employed for this investigation and all available and qualifying lipid panels for any patient who had an AMI were analyzed. The main outcome was evaluating the medication management of the residual risk patient group with a focus on the initiation of niacin. A computerized list of patients with an AMI ICD-9 code was generated by the Medical Informatics Department at St Rose Hospital, which allowed the identification of potential study subjects. All data were obtained from the electronic database. Patients could not be entered into the residual risk study population more than once.

\section{Definitions}

All definitions were identified prospectively as part of the original study design. A positive troponin was defined as $\geq 0.2 \mathrm{ng} / \mathrm{mL}$. For the residual risk study population lipid goals and risk factors were defined by the current National Cholesterol Education Panel (NCEP) guidelines. ${ }^{18}$ Initiation of niacin and other medication interventions regarding lipids were recorded if the patient received the medication while admitted or had the drug listed in the discharge medication list.

\section{Statistical analysis}

PASW version 17.0 was employed for statistical analysis. The data were classified as either nominal or continuous and chi-squared tests and independent t-tests were utilized, respectively. The primary data analysis compared residual risk patients initiated on niacin versus other medical management to determine differing characteristics between these groups.

\section{RESULTS}

\section{Patients}

A total of 1113 patients were evaluated for inclusion. Patients were excluded for the following reasons (Figure 1): $142(12.8 \%)$ did not have a positive troponin value, $403(36.2 \%)$ did not have a lipid panel within 96 hours of the positive troponin, and $15(1.3 \%)$ had a triglyceride value of $>400$ $\mathrm{mg} / \mathrm{dL}$. A total of 553 patients experiencing an AMI with subsequent lipid panels were eligible for inclusion into the residual risk group. 


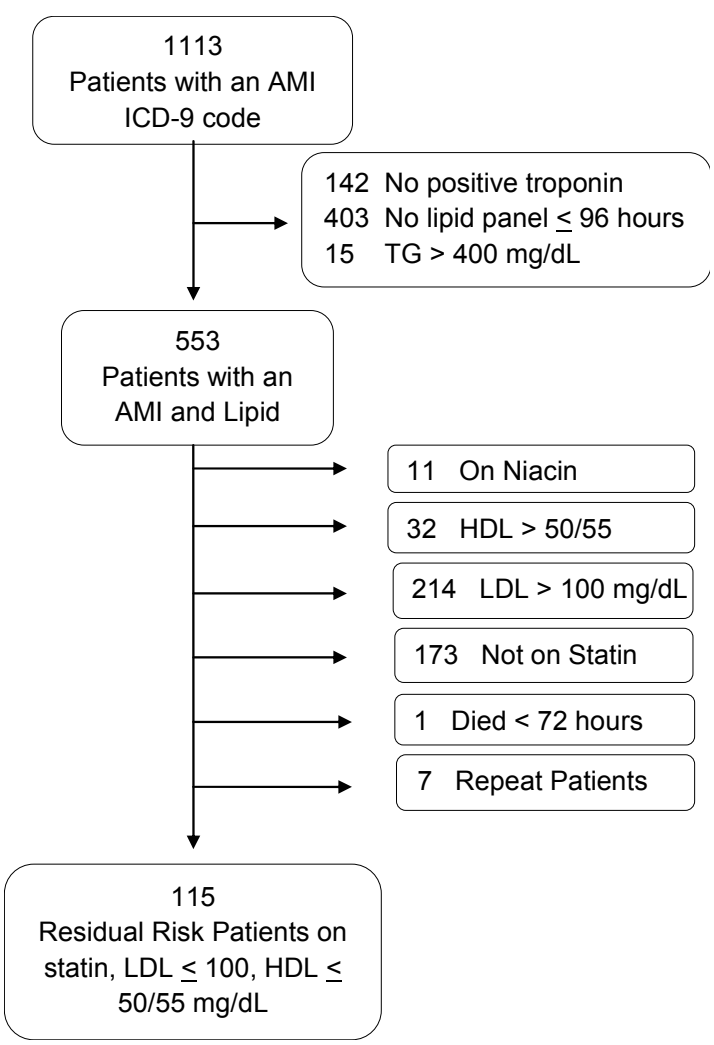

Figure 1: Flow chart of patients included in the study and reasons for exclusion

\section{Patients with AMI and Lipid Panel}

The mean LDL was $97.3(\mathrm{SD}=36.0) \mathrm{mg} / \mathrm{dL}$, mean $\mathrm{HDL}$ was $33.5(\mathrm{SD}=11.1) \mathrm{mg} / \mathrm{dL}$, and mean $\mathrm{TG}$ was $133.1(\mathrm{SD}=71.3) \mathrm{mg} / \mathrm{dL}$ (Table 1). Of these patients, $459(83.0 \%)$ patients had an $\mathrm{LDL}<130 \mathrm{mg} / \mathrm{dL}, 317$ $(57.3 \%)$ had and LDL<100 mg/dL, and $144(26.0 \%)$ had an $\mathrm{LDL}<70 \mathrm{mg} / \mathrm{dL}$. The majority of patients $(\mathrm{n}=521,94.2 \%)$ had an $\mathrm{HDL}<50$ or $55 \mathrm{mg} / \mathrm{dL}$ respective of gender (Figure 2). Of the 317 patients experiencing an AMl while at LDL of $<100 \mathrm{mg} / \mathrm{dL}$, $303(95.6 \%)$ of them were not at HDL goal and of the 144 patients at the optional goal LDL $<70 \mathrm{mg} / \mathrm{dL}$, $136(94.4 \%)$ were not at HDL goal. One hundred and eighty-one $(32.7 \%)$ patients had a statin listed in their medication list. From this group of patients on statins, $137(75.7 \%)$ had an $\mathrm{LDL}<100 \mathrm{mg} / \mathrm{dL}$, $171(94.5 \%)$ had an $\mathrm{HDL}<50 / 55 \mathrm{mg} / \mathrm{dL}$, and 130 (71.8\%) patients had and $\mathrm{LDL}<100 \mathrm{mg} / \mathrm{dL}$ and an $\mathrm{HDL}<50 / 55 \mathrm{mg} / \mathrm{dL}$. Eleven patients $(2.0 \%)$ were on niacin as a home medication.

\section{Residual Risk Patients}

Of these $553 \mathrm{AMI}$ patients, 115 patients met criteria as the residual risk patient population and were evaluated for medication management (Figure 1). Demographics evaluated for residual risk patients are listed in Table 2.

Ninety-two (80.0\%) residual risk patients had no change in their home lipid medications post AMI (Table 3). Of the $23(20.0 \%)$ patients with interventions, $15(13.0 \%)$ had their statin dose increased. The average LDL of these 15 patients was $69.3(\mathrm{SD}=16.0) \mathrm{mg} / \mathrm{dL}$, and $8(53.3 \%)$ of these patients had an LDL of $<70 \mathrm{mg} / \mathrm{dL}$ and $12(80.0 \%)$

\begin{tabular}{|l|c|}
\hline \multicolumn{2}{|c|}{ Table 1: Baseline Characteristics of AMI Patients } \\
\hline \multicolumn{1}{|c|}{ Baseline Characteristic } & $\mathrm{N}=553$ \\
\hline $\mathrm{LDL}(\mathrm{mg} / \mathrm{dL})$, mean (SD) & $97.3(36.0)$ \\
\hline $\mathrm{HDL}(\mathrm{mg} / \mathrm{dL})$, mean (SD) & $33.5(11.1)$ \\
\hline $\mathrm{TC}(\mathrm{mg} / \mathrm{dL})$, mean (SD) & $157.8(40.9)$ \\
\hline $\mathrm{TG}(\mathrm{mg} / \mathrm{dL}), \mathrm{mean}(\mathrm{SD})$ & $133.1(71.3)$ \\
\hline $\mathrm{TC} / \mathrm{HDL}(\mathrm{mg} / \mathrm{dL}), \mathrm{mean}(\mathrm{SD})$ & $5.1(1.9)$ \\
\hline $\mathrm{LDL} \leq 70 \mathrm{mg} / \mathrm{dL}, \mathrm{n}(\%)$ & $144(26.0 \%)$ \\
\hline $\mathrm{LDL} \leq 100 \mathrm{mg} / \mathrm{dL}, \mathrm{n}(\%)$ & $317(57.4 \%)$ \\
\hline $\mathrm{LDL} \leq 130 \mathrm{mg} / \mathrm{dL}, \mathrm{n}(\%)$ & $459(82.9 \%)$ \\
\hline $\mathrm{HDL} \leq 50 / 55 \mathrm{mg} / \mathrm{dL}, \mathrm{n}(\%)$ & $521(94.2 \%)$ \\
\hline On statin, $\mathrm{n}(\%)$ & $181(32.7 \%)$ \\
\hline On niacin, $\mathrm{n}(\%)$ & $11(2.1 \%)$ \\
\hline Residual $\mathrm{risk}, \mathrm{n}(\%)$ & $130(24.3 \%)$ \\
\hline
\end{tabular}

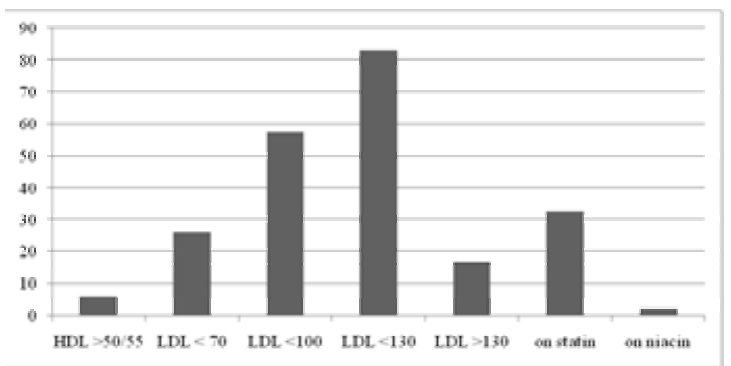

Figure 2: Bar graph of characteristics of acute myocardial infarction (AMI) patients ( $\mathrm{x}$ axis) and percent of patients (y axis)

had an HDL of $<40 \mathrm{mg} / \mathrm{dL}$. Seven $(6.1 \%)$ residual risk patients were initiated on niacin, and the average $\mathrm{LDL}$ was $72.6(\mathrm{SD}=14.1) \mathrm{mg} / \mathrm{dL}$ and all patients had an HDL of $<40 \mathrm{mg} / \mathrm{dL}$.

\section{DISCUSSION}

The study results confirm an existence of a residual risk population with nearly $25 \%$ of $\mathrm{AMI}$ patients meeting the criteria. This presence of a residual risk may suggest statin monotherapy for the management of dyslipidemia may not be sufficient. The lipid panel results of all AMI patients validate the interest in low HDL as a target therapy beyond LDL lowering, as $94.2 \%$ of AMI patients were not at HDL goal but $57.4 \%$ were at an LDL goal of $<100$ $\mathrm{mg} / \mathrm{dL}$. The results also confirm a low incidence of medication intervention in the residual risk population post AMI $(20.0 \%)$ regarding lipid therapy, including the initiation of niacin in only $6.1 \%$ of residual risk patients.

Perhaps the importance of residual risk is overlooked because of the order and focus of the goals listed in the cholesterol guidelines. In 2001, the guidelines for Detection, Evaluation, and Treatment of High Blood Cholesterol in Adults: Adult Treatment Panel III (ATPIII) identified LDL as the primary target of therapy. ${ }^{19}$ The document describes specific LDL goals for three different risk categories, and a statin is listed as the drug of choice for LDL lowering. Metabolic syndrome, defined as an assemblage of lipid and nonlipid risk factors, and hypertriglyceridemia are listed as a potential secondary targets and treatment goals are also described in detail. Although low HDL is part of the possible diagnostic criteria for metabolic syndrome, it is not mentioned as a specific patient population in the original 2001 ATPIII publication. 


\begin{tabular}{|l|c|c|c|}
\hline Table 2: Characteristics of Residual Risk Patients & p value \\
\hline Characteristic & $\begin{array}{c}\text { Niacin Initiated } \\
(\mathrm{n}=7)\end{array}$ & $\begin{array}{c}\text { No Niacin } \\
(\mathrm{n}=108)\end{array}$ & 0.869 \\
\hline Age, mean (SD) & $67.0(13.8)$ & $67.8(12.0)$ & 0.609 \\
\hline Male, $\mathrm{n}(\%)$ & $5(71.4 \%)$ & $79(73.1 \%)$ & 0.814 \\
\hline $\mathrm{BMI}$, mean (SD) & $29.1(4.5)$ & $28.7(5.4)$ & 0.478 \\
\hline $\mathrm{LDL}$, mean (SD) & $72.6(13.4)$ & $67.8(17.3)$ & 0.322 \\
\hline $\mathrm{HDL}$, mean (SD) & $28.7(4.0)$ & $32.2(9.2)$ & 0.556 \\
\hline TC, mean (SD) & $129.3(5.8)$ & $123.5(26.0)$ & 0.493 \\
\hline TG, mean (SD) & $139.0(70.5)$ & $122.7(60.3)$ & 0.386 \\
\hline TC/HDL, mean (SD) & $4.6(0.9)$ & $4.1(1.4)$ & 0.881 \\
\hline Gout, $\mathrm{n}(\%)$ & $0(0 \%)$ & $2(1.9 \%)$ & 0.443 \\
\hline Diabetes, $\mathrm{n}(\%)$ & $3(42.9 \%)$ & $36(33.3 \%)$ & 0.401 \\
\hline $\mathrm{HTN}, \mathrm{n}(\%)$ & $5(71.4 \%)$ & $88(81.5 \%)$ & 0.599 \\
\hline Hx of AMl, $\mathrm{n}(\%)$ & $1(14.3 \%)$ & $21(19.4 \%)$ & 0.157 \\
\hline Hx of PCl, $\mathrm{n}(\%)$ & $3(42.9 \%)$ & $21(19.4 \%)$ & 0.038 \\
\hline $\mathrm{Hx}$ of CABG, $\mathrm{n}(\%)$ & $3(42.9 \%)$ & $11(10.2 \%)$ & 0.361 \\
\hline Tobacco, $\mathrm{n}(\%)$ & $3(42.9 \%)$ & $32(29.6 \%)$ & 0.024 \\
\hline Family Hx, $\mathrm{n}(\%)$ & $4(57.1 \%)$ & $18(16.7 \%)$ & 0.234 \\
\hline Concurrent lipid therapy, $\mathrm{n}(\%)$ & $0(0 \%)$ & $21(18.3 \%)$ & \\
\hline
\end{tabular}

\begin{tabular}{|l|c|c|c|c|c|}
\hline \multicolumn{7}{|l|}{ Table 3: Medication Management of Lipids in Residual Risk Patients } \\
\hline \multicolumn{1}{|c|}{ Intervention } & $\mathrm{n}=115(\%)$ & $\mathrm{LDL}, \mathrm{avg}(\mathrm{SD})$ & $\mathrm{HDL}$, avg. (SD) & $\mathrm{LDL}<70, \mathrm{n}$ & $\mathrm{HDL}<40, \mathrm{n}$ \\
\hline No Intervention & $92(80.0 \%)$ & $67.6(17.5)$ & $32.3(9.0)$ & 52 & 22 \\
\hline Any Intervention & $23(20.0 \%)$ & $70.1(15.6)$ & $30.6(8.0)$ & 12 & 20 \\
\hline Increased Statin Dose & $15(13.0 \%)$ & $69.3(16.0)$ & $31.7(9.2)$ & 8 & 12 \\
\hline Initiated Niacin & $7(6.1 \%)$ & $72.6(14.1)$ & $28.7(2.9)$ & 3 & 7 \\
\hline Initiated Omega-3s & $1(0.9 \%)$ & 50 & 23 & 1 & 1 \\
\hline Initiated Fibrate & $1(0.9 \%)$ & 97 & 35 & 0 & 1 \\
\hline Initiated Ezetimibe & $1(0.9 \%)$ & 95 & 48 & 0 & 0 \\
\hline
\end{tabular}

ATPIII 2004 update mentions HDL a limited number of times and states its importance as a strong independent predictor of CHD, but does not focus on the treatment of low HDL until the Special Issues section and after addressing very high LDL and elevated triglycerides. ${ }^{18}$ The panel did increase the definition of low HDL from $<35$ to $<40 \mathrm{mg} / \mathrm{dL}$ when comparing ATPII to ATPIII, but does not specify a treatment goal for HDL. It is suggested all patients with low HDL should follow the treatment sequence to first meet LDL goal, weight and activity goals, $\mathrm{TG}<200 \mathrm{mg} / \mathrm{dL}$, then HDL goal. It also states that treatment for isolated low HDL when all other goals met is reserved for $\mathrm{CHD}$ and $\mathrm{CHD}$ risk equivalent patients, and fibrates or nicotinic acid can be considered. Our study clearly identifies the need to increase the level of interest in HDL, as all patients in the residual risk population were on a statin, at LDL and TG goals, and still experiencing AMIs.

Although ATPIII states that currently no drugs robustly increase HDL, niacin and statin/niacin combination therapy has been shown to significantly increase HDL levels compared to placebo, highdose statin therapy, ezetimibe, and fibric acids in the trials previously mentioned as well as the COMPELL trial ${ }^{20}$ and SEACOAST-1 trial. $^{21}$

The influence of the ATPIII guidelines and focus on LDL and TG therapy is also reflected in the number of dispensed prescriptions with atorvastatin, simvastatin, rosuvastatin, simvastatin/ezetimibe combination, ezetimibe, and fenofibrate all listed in the top 50 in 2008 and niacin listed at $151 .{ }^{22}$ Another possibility is that therapy with statins and other cholesterol medications is thought to increase
HDL sufficiently. However it has been shown in several of the trials discussed above as well as the FIELDS study that high-dose statins and other cholesterol medications do not significantly increase HDL concentrations. ${ }^{3,13,20,21,23,24}$

Additional reasons for the low-incidence of niacin initiation could be the side effect of flushing and the increase in serum glucose in diabetic patients. It is important to mention that flushing was rarely a cause for dropout in trials using extended-release niacin. ${ }^{25}$ Secondly, the increase in serum glucose is low (4 to 5\%) and transient. ${ }^{25,26}$ These changes in blood glucose levels are considered to be safe by the American Heart Association, National Lipid Association, American Diabetes Association, and National Cholesterol Education Program and furthermore suggest the cardiovascular benefits may outweigh the risks. ${ }^{19,27-29}$

This study had several limitations. First, a lipid panel was not obtained on over $40 \%$ of AMI patients, and this missing data could have altered the results. All data was collected from the electronic database, some patients may have been wrongfully excluded or included due to missing information that could have been obtained from a paper chart review. Another perceived limitation could be the inaccuracy of lipid panels in the time frame surrounding an AMI.

There has been some controversy in the past regarding the measurement of lipids outside of the 24 hour period post acute coronary syndrome as suggested by the American College of Cardiology/American Heart Association (ACC/AHA) ${ }^{30,31}$ This is due to the believed transient decline in serum lipid levels occurring after the 24 
hour mark and potentially persisting for nearly a year. ${ }^{32-36}$ Data by Pitt $B$, et al. published after the ACC/AHA guidelines has shown lipid levels are stable within the 96 hour window post AMI. ${ }^{17}$ The contradictory finding is likely due to the weakness of previous trials assessing calculated serum lipid levels within this time frame. Strengths of the more recent trial include a more robust study population; more than double the number of patients of the previously referenced studies combined, prospective design, direct lipid measurements, and contemporary medical practice. Measuring LDL directly as opposed to calculating eliminates falsely elevated LDL in non-fasting patients due to elevated triglyceride levels. ${ }^{37}$ Contemporary medicine is an important distinction when considering the advancement of percutaneous coronary interventions and thrombolytic therapy because the extent of lipid alteration has been directly correlated to the extent of myocardial necrosis. ${ }^{34}$ Based on the strength of this evidence we chose to include serum lipid measurements up to 96 hours in our study.

\section{CONCLUSIONS}

This study supports a need to address low HDL in residual risk patients. The direct relationship between HDL and CVE needs to be further investigated in prospective, randomized trials. The AIM-HIGH and HPS2-THRIVE trials will help to elucidate this correlation. However while awaiting these results, physicians and pharmacists can potentially impact patient outcomes by identifying these residual risk patients and appropriately addressing their HDL.

\section{CONFLICT OF INTEREST}

No conflicts of interest exist among the investigators in this study.

\section{References}

1. Heron M, Hoyert DL, Murrphy SL. Xu J, Kochanek KD, Tejada-Vera B. Deaths: final data for 2006. NVSS. 2009;59:1135.

2. Natarajan $P$, Ray KK, Cannon CP. High-density lipoprotein and coronary heart disease: Current and future therapies. J Am Coll Cardiol. 2010;55:1283-1299.

3. Gordon DJ, Probstfield JL, Garrison RJ, Neaton JD, Castelli WP, Knoke JD, Jacobs DR Jr, Bangdiwala S, Tyroler HA. High-density lipoprotein cholesterol and cardiovascular disease: Four prospective American studies. Circulation. 1989;79:8-15.

4. Bruckert E. Epidemiology of low HDL-cholesterol: Results of studies and surveys. Eur Heart J. 2006;8:F17-F22.

5. Carlson LA, Hamsten A, Asplund A. Pronounced lowering of serum levels of lipoprotein L $p(a)$ in hyperlipidaemic subjects treated with nicotinic acid. J Intern Med. 1989;226:271-276.

6. Capuzzi DM, Guyton JR, Morgan JM, Goldberg AC, Kreisberg RA, Brusco OA, Brody J. Efficacy and safety of an extended-release niacin (Niaspan): a long-term study. Am J Cardiol. 1998;82:U74-81.

7. Guyton JR, Goldberg AC, Kreisberg RA, Sprecher DL, Superko HR, O'Connor CM. Effectiveness of once-nightly dosing of extended-release niacin alone and in combination for hypercholesterolemia. Am J Cardiol. 1998;82:737-743.

8. McKenney JM, McCormick LS, Weiss S, Koren M, Kafonek S, Black DM. A randomized trial of the effects of atorvastatin and niacin in patients with combined hyperlipidemia or isolated hypertriglyceridemia. Collaborative atorvastatin study group. Am J Med. 1998;104:137-143.

9. Knopp RH. Drug treatment of lipid disorders. N Engl J Med. 1999;341:498-511.

10. Fruchart JC, Sacks FM, Hermans MP, Assmann G, Brown WV, Ceska R, Chapman MJ, Dodson PM, Fioretto P, Ginsberg HN, Kadowaki T, Lablanche JM, Marx N, Plutzky J, Reiner Z, Rosenson RS, Staels B, Stock JK, Sy R, Wanner C, Zambon A, Zimmet P; A Condensed Position Paper by the Residual Risk Reduction Initiative (R3I). The residual risk reduction initiative: A call to action to reduce residual vascular risk in dyslipidaemic patients. Perspectives 2008;5:319-335.

11. Barter P, Gotto AM, LaRosa JC. HDL cholesterol, very low levels of LDL cholesterol, and cardiovascular events. N Engl J Med. 2007;357:1301-1311.

12. Brown BG, Zhao XQ, Chait AC, Cheung MC, Morse JS, Dowdy AA, Marino EK, Bolson EL, Alaupovic P, Frohlich J, Albers JJ. Simvastatin and niacin, antioxidant vitamins, or the combination for the prevention of coronary disease. $N$ Engl J Med. 2001;345:1583-1592.

13. Taylor AJ, Sullenberger LE, Lee HJ, Lee JK, Grace KA. Arterial biology for the investigation of treatment effects of reducting cholesterol (ARBITER) 2: A double-blind, placebo-controlled study of extended-release niacin on atherosclerosis progression in secondary prevention patients treated with statins. Circulation. 2004;110:3512-3517.

14. Whitney EJ, Krasuski RA, Personius BE, Michalek JE, Maranian AM, Kolasa MW, Monick E, Brown BG, Gotto AM Jr. A randomized trial of strategy for increasing high-density lipoprotein cholesterol levels: Effects on progression of coronary heart disease and clnical events. Ann Intern Med. 2005;142:95-104.

15. Canner PL, Berge KG, Wenger NK, Stamler J, Friedman L, Prineas RJ, Friedewald W. Fifteen year mortality in Coronary Drug Project patients: long-term benefit with niacin. J Am Coll Cardiol. 1986;8:1245-1255.

16. Taylor AJ, Villines TC, Stanek EJ, Devine PJ, Griffen L, Miller M, Weissman NJ, Turco M. Extended-release niacin or ezetimibe and carotid intima-media thickness. N Engl J Med. 2009;361:2113-2122.

17. Pitt B, Loscalzo J, Ycas J, Raichlen JS. Lipid levels after acute coronary syndrome. J Am Coll Cardiol. 2008;51:14401445.

18. Grundy SM, Cleeman JI, Merz CN, Brewer HB Jr, Clark LT, Hunninghake DB, Pasternak RC, Smith SC Jr, Stone NJ; National Heart, Lung, and Blood Institute; American College of Cardiology Foundation; American Heart Association. 
Implications of recent clinical trials for the National Cholesterol Education Program Adult Treatment Panel III guidelines. Circulation. 2004;110:227-239.

19. Third Report of the National Cholesterol Education Program (NCEP) Expert Panel on Detection, Evaluation, and Treatment of High Blood Cholesterol in Adults (Adult Treatment Panel III) Executive Summary. NIH Publication. 2001;01-3670:1-28.

20. McKenney JM, Jones PH, Bays HE, Knopp RH, Kashyap ML, Ruoff GE, McGovern ME. Comparative effects on lipid levels of combination therapy with a statin and extended-release niacin or ezetimibe versus statin alone (the COMPELL study). Atherosclerosis. 2007;192:432-437.

21. Ballantyne CM, Davidson MH, McKenney J, Keller LH, Bajorunas DR, Karas RH. Comparison of the safety and efficacy of a combination tablet of niacin extended release and simvastatin vs simvastatin monotherapy in patients with increased non-HDL cholesterol. Am J Cardiol. 2008;101:1428-1436.

22. Rx Focus: top 200 drugs of 2008, May 2009. Available from www.pharmacytimes.com/issue/pharmacy/2009/200905/RxFocusTop200Drugs-0509 (Accessed March 13, 2010).

23. Keech A, Simes RJ, Barter P, Best J, Scott R, Taskinen MR, Forder P, Pillai A, Davis T, Glasziou P, Drury P, Kesäniemi YA, Sullivan D, Hunt D, Colman P, d'Emden M, Whiting M, Ehnholm C, Laakso M; FIELD study investigators. Effects of long-term fenofibrate therapy on cardiovascular events in 9795 people with type 2 diabetes mellitus (the FIELD study) randomised controlled trial. Lancet. 2005;366:1849-1861.

24. LaRosa JC, Grundy SM, Waters DD, Shear C, Barter P, Fruchart JC, Gotto AM, Greten H, Kastelein JJ, Shepherd J, Wenger NK; Treating to New Targets (TNT) Investigators. Intensive lipid lowering with atorvastatin in patients with stable coronary disease. N Engl J Med. 2005;352:1425-1435.

25. Zhao XQ, Morse JS, Dowdy AA, Heise N, DeAngelis D, Frohlich J, Chait A, Albers JJ, Brown BG. Safety and tolerability of simvastatin plus niacin in patients with coronary artery disease and low high-density lipoprotein cholesterol. Am J Cardiol. 2004;93:307-312.

26. Grundy SM, Vega GL, McGovern ME, Tulloch BR, Kendall DM, Fitz-Patrick D, Ganda OP, Rosenson RS, Buse JB, Robertson DD, Sheehan JP; Diabetes Multicenter Research Group. Efficacy, safety, and tolerability of once-daily niacin for the treatment of dyslipidemia associated with type 2 diabetes: results of the assessment of diabetes control and evaluation of the efficacy of Niaspan trial. Arch Intern Med. 2002;162:1568-1576.

27. Buse JB, Ginsberg HN, Bakris GL, Clark NG, Costa F, Eckel R, Fonseca V, Gerstein HC, Grundy S, Nesto RW, Pignone MP, Plutzky J, Porte D, Redberg R, Stitzel KF, Stone NJ; American Heart Association; American Diabetes Association. Primary prevention of cardiovascular diseases in people with diabetes mellitus: a scientific statement from the American Heart Association and the American Diabetes Association. Circulation. 2007;115:114-126.

28. American Diabetes Association. Standards of medical care in diabetes-2007. Diabetes Care. 2007;30(Suppl 1):4-41.

29. Guyton JR, Bays HE. Safety considerations with niacin therapy. Am J Cardiol. 2007;99:C22-31.

30. Anderson JL, Adams CD, Antman EM, Bridges CR, Califf RM, Casey DE Jr, Chavey WE II, Fesmire FM, Hochman JS, Levin TN, Lincoff AM, Peterson ED, Theroux P, Wenger NK, Wright RS, Smith SC Jr, Jacobs AK, Adams CD, Anderson JL, Antman EM, Halperin JL, Hunt SA, Krumholz HM, Kushner FG, Lytle BW, Nishimura R, Ornato JP, Page RL, Riegel B. ACC/AHA 2007 guidelines for the management of patients with unstable angina/non- ST-elevation myocardial infarction: a report of the American College of Cardiology/American Heart Association Task Force on Practice Guidelines (Writing Committee to Revise the 2002 Guidelines for the Management of Patients With Unstable Angina/Non-ST-Elevation Myocardial Infarction). J Am Coll Cardiol. 2007;50:e1-e157.

31. Antman EM, Hand M, Armstrong PW, Bates ER, Green LA, Halasyamani LK, Hochman JS, Krumholz HM, Lamas GA, Mullany CJ, Pearle DL, Sloan MA, Smith SC Jr; 2004 Writing Committee Members, Anbe DT, Kushner FG, Ornato JP, Jacobs AK, Adams CD, Anderson JL, Buller CE, Creager MA, Ettinger SM, Halperin JL, Hunt SA, Lytle BW, Nishimura R, Page RL, Riegel B, Tarkington LG, Yancy CW. 2007 Focused update of the ACC/AHA 2004 guidelines for the management of patients with ST-elevation myocardial infarction: a report of the American College of Cardiology/American Heart Association Task Force on Practice Guidelines: developed in collaboration with the Canadian Cardiovascular Society Endorsed by the American Academy of Family Physicians: 2007 Writing Group to review new evidence and update the ACC/AHA 2004 guidelines for the management of patients with ST-elevation myocardial infarction, writing on behalf of the 2004 writing committee. Circulation. 2008;117;296-329.

32. Dodds C, Mills GL. Influence of myocardial infarction on plasma lipoprotein concentration. Lancet 1959;1:1160-1163.

33. Tibblin G, Cramer K. Serum lipids during the course of an acute myocardial infarction and one year afterwards. Acta Med Scand. 1963;174:451-455

34. Fyfe T, Baxter RH, Cochran KM, Booth EM. Plasma-lipid changes after myocardial infarction. Lancet. 1971;2:997-1001.

35. Kirkeby K. Disturbances in serum lipids and in their fatty acid composition following acute myocardial infarction. Acta Med Scand. 1972;192:523-528.

36. Ryder RE, Hayes TM, Mulligan IP, Kingswood JC, Williams S, Owens DR. How soon after myocardial infarction should plasma lipid values be assessed? BMJ. 1984;289:1651-1653.

37. Friedewald WT, Levy RI, Fredrickson DS. Estimation of the concentration of low-density lipoprotein cholesterol in plasma, without use of the preparative ultracentrifuge. Clin Chem. 1972;18:499-502. 